\title{
Report (1966-1970) of the Subcommittee on the Taxonomy of Leptospira to the International Committee on Nomenclature of Bacteria
}

\author{
13 August 1970
}

\section{Mexico City, Mexico}

The recommendation [Subcommittee Report (1962), Int. Bull. Bacteriol. Nomencl. Taxon., 13:161-165] that the genus Leptospira be divided into two species was altered in Moscow because the reactions proposed for distinguishing between the two proposed species were suspected to be unreliable. It was then agreed by a majority that the genus be considered monospecific until adequate data had been collected. The specific epithet interrogans was recommended for use in the species name. There are problems connected with the nomenclatural type of the single species of Leptospira which have not yet been resolved.

It was further agreed that though there were inadequate data for circumscribing two species, at least two main groups were discernible-more or less corresponding with the two previously proposed species-and that these groups be termed "complexes" as a temporary expedient.
The working taxon in this genus is serotype, and this is based on agglutinogenic characters. Recent investigations into the variables involved in the serotyping of strains suggest that a reliable standardization of methods will be achieved.

C. Borg-Petersen was elected chairman in 1966, J. W. Wolff having served his term.

The present members and officers of the Subcommittee are: C. Borg-Petersen (Chairman), Copenhagen, Denmark; L. H. Turner (Secretary), London, England; A. D. Alexander, Washington, D.C., USA; B. Babudieri, Rome, Italy; S. Faine, Melbourne, Victoria, Australia; R. C. Johnson, Minneapolis, Minnesota, USA; E. Kmety, Bratislava, Czechoslovakia; M. Torten, Ness-Ziona, Israel; A. A. Varfolomeeva, Moscow, USSR.

L. H. Turner, Secretary

C. Borg-Petersen, Chairman 